\title{
Wheat Germ: An Overview on Nutritional Value, Antioxidant Potential and Antibacterial Characteristics
}

\author{
Awad A. Mahmoud ${ }^{1}$, Adel A. A. Mohdaly ${ }^{1,2}$, Nady A. A. Elneairy ${ }^{{ }^{*}}$ \\ ${ }^{1}$ Food Science and Technology, Faculty of Agriculture, Fayoum University, Al Fayoum, Egypt \\ ${ }^{2}$ Plant Production and Processing Department, Food Management Course, Agricultural Faculty, University of \\ Applied Sciences Weihenstephan-Triesdorf, Triesdorf, Germany \\ Email: ${ }^{\text {nadyelneairy@yahoo.com }}$
}

Received 22 January 2015; accepted 8 February 2015; published 12 February 2015

Copyright (C) 2015 by authors and Scientific Research Publishing Inc.

This work is licensed under the Creative Commons Attribution International License (CC BY). http://creativecommons.org/licenses/by/4.0/

(c) (i) Open Access

\begin{abstract}
Wheat germ is a by-product derived from the wheat milling industry. Defatted wheat germ is the main by-product of the wheat germ in the oil extraction process. This study aims at development of efficient and low cost processing methods to transform these residues in added value co-product. In this study, wheat germ was analysed for its proximate composition, fatty acid composition, physical and chemical characteristics of wheat germ oil. The basic chemical composition analyses revealed high values of dry matter $(87.37 \mathrm{~g} / 100 \mathrm{~g} \mathrm{FW})$, significant amounts of total protein and fat (27.69 and $8.99 \mathrm{~g} / 100 \mathrm{~g}$ FW, respectively) content and low ash content $(3.08 \mathrm{~g} / 100 \mathrm{~g}$ FW). The quality of the extracted oils was assessed in terms of acid value, iodine value, saponification value, peroxide value, refractive index, and unsaponifiable matter. The fatty acid profile was found to be made up of linoleic followed by palmitic and oleic as the major fatty acids. Antioxidant properties and in vitro antibacterial activity of defatted wheat germ (DWG) extract were also determined. DWG, as a source of natural antioxidants and antibacterial, could be used to formulate nutraceuticals with potential applications to reduce the level of oxidative stress. The antioxidant potency of the DWG extracts could be the basis for its health promoting potential. The results showed that these by-products could be used as a source of bioactive compounds beneficial for health.
\end{abstract}

\section{Keywords}

Antibacterial Activity, Antioxidant Properties, Defatted Wheat Germ, Fatty Acid, Wheat Germ Oil

\footnotetext{
${ }^{*}$ Corresponding author.
}

How to cite this paper: Mahmoud, A.A., Mohdaly, A.A.A. and Elneairy, N.A.A. (2015) Wheat Germ: An Overview on Nutritional Value, Antioxidant Potential and Antibacterial Characteristics. Food and Nutrition Sciences, 6, 265-277. 


\section{Introduction}

There is an increasing awareness of the importance of vegetable oils as sources of food, biofuel, health enhancing compounds, i.e., nutraceuticals, as feedstock for industrial polymers and for many other industrial products. Thus the world demand for vegetable oils is set to rise even more rapidly from year to year, and this trend will impact on the price levels of oils. Oil World indicated in its 2011 reported [1] that vegetable oil world production was not sufficient to satisfy global demand for food and for oleochemical industry as well as for the energy sector. Total global consumption of vegetable oils has increased 3.6 percent to 176 million tonnes in 2011, from 170 million tonnes in 2010. About 60 percent of the increase was used in the food industry to meet demand from a rising population, leaving only 2.4 million tons for the energy market and oleochemical industry [1].

Cereals have an important role in human nutrition, either for cooking or as raw material for obtaining flour for baking. Botanically they belong to the grass family (Gramineae), that include wheat, maize, rice, oats, barley, millets, sorghum, and rye [2]. Wheat is one of the major cereals and food ingredients across the world due to its ability to be ground into flour. The flour extraction rate ranges from $73 \%$ to $77 \%$, depending on the variety of wheat, the cultivation conditions and the milling process [3]. Thus, by-product streams including wheat germ, wheat bran and parts of the endosperm amount for about $23 \%$ - 27\% of the milling output. Assuming that all wheat for human food consumption is milled, the by-product stream would account for about 150 million tons per year.

Wheat germ (WG) is widely recognized as a nutritious raw material for incorporation into food product formulations or as a food in its own right. Typical applications are in germ-enriched bread, snack foods, and supplements to breakfast cereals, and for production of wheat-germ oil. Wheat germ, containing about $8 \%-14 \%$ oil (average 10\%), is mainly used in food, medical and cosmetic industries as a source of oil [4]. Relatively a huge quantity of wheat germ is produced annually as a by-product of wheat milling industry in Egypt. In 2012, it was reported that about 120,000 tons wheat germ were produced from wheat milling. This quantity can yield about 12,000 ton wheat germ oil annually. Unfortunately, the whole quantity of the germ produced is currently utilized in the production of animal fodder [5]. It is advisable therefore that this by-product would be rather utilized for oil production.

In recent years, there is a growing interest to identify antioxidative properties in many natural sources due to the potential health hazards of some synthetic antioxidants. Defatted wheat germ (DWG), the main by-product in the wheat germ oil extraction process, has relatively high protein content (30\%) and contains many other nutritional ingredients, such as carbohydrates, pigments, minerals, and B vitamins [4]. However, few systematic studies have been found on DWG antioxidants. Furthermore, the phenolics in DWG have been less treated in terms of their contents and contribution to the overall antioxidant activities of DWG. As a matter of fact, due to the complex nature of phytochemicals, their antioxidant activity should be evaluated using several commonly accepted assays.

The research area of food technology still faces great challenges in finding alternative ways of adding value to produced foodstuffs and, moreover, in maintaining their quality and safety. Therefore, in this paper, effort has been made to analyze oil recovery, physico-chemical properties, and fatty acid composition of wheat germ. In addition, defatted wheat germ extracts (DWGE) were obtained using hexane as a solvent, and determined for its antioxidant activity by in vitro methods, including 1,1-diphenyl-2-picrylhydrazyl (DPPH) scavenging assay, Rancimat method, and 2, 2'-Azinobis (3-ethylbenzothiazoline-6 sulfonic acid) (ABTS) scavenging assay. We measured the antibacterial activity against Gram-positive bacteria (Listeria monocytogenes and Staphylococcus aureus), and Gram-negative bacteria (Salmonella enterica and Escherichia coli).

\section{Materials and Methods}

\subsection{Plant Material and Reagents}

Wheat (Triricum aestivum) germ purchased from Middle Egypt Flour Mills Company, Fayoum Governorate, Egypt, was carefully cleaned to remove contaminates. The germ collected was stored in an airtight container in a freezer $\left(-20^{\circ} \mathrm{C}\right)$ until it was further used for different experiments. Standards used for fatty acids and 2, 2'-Azinobis (3-ethylbenzothiazoline-6 sulfonic acid) (ABTS) were purchased from Sigma (St Louis, MO, Germany). 1,1-diphenyl-2-picrylhydrazyl (DPPH), was obtained from Fluka (Buchs, Switzerland). Reagents and chemicals used were of the highest purity available. 


\subsection{Proximate Analyses of Wheat Germ}

The major chemical constituent, moisture, ash, crude fat, crude fiber, and crude protein were determined in triplicate according to AOAC standard methods [6]. Carbohydrate content was calculated by difference as the sum of the moisture, fat, protein, fiber, and ash contents were subtracted from 100 as outlined in AOAC [6]. The food energy value of the seeds was obtained by multiplying the mean value of the protein, fat, and carbohydrate by Atwater factors of 4, 9, and 4, respectively, and expressing the sum of the products in kilocalories.

\subsection{Oil Extraction}

About 250 grams of wheat germ were ground in a blender and the oil was extracted by four successive extractions with purified n-hexane (1:3 w/v) at room temperature. The miscella was separated from the cake by filtration with Whatman No. 1 filter paper. The filtrate miscella, were combined and n-hexane was removed under vacuum, at $50^{\circ} \mathrm{C}$, in a rotary evaporator. The obtained oil was dried over anhydrous sodium sulphate then, directly analyzed.

\subsection{Physicochemical Properties of Wheat Germ Oil}

\subsubsection{Physical Constants}

The refractive index of extracted oil was measured according to AOAC [6] using Abbe refractometer at $25^{\circ} \mathrm{C}$. The method described by Lee et al. [7] was applied for determination of color; the absorbance of $5 \%(\mathrm{w} / \mathrm{v})$ solutions of oil in chloroform was measured at $420 \mathrm{~nm}$ using a "spectronic 20" spectrophotometer (Bauch \& Lamb).

\subsubsection{Chemical Constants}

The iodine value, saponification value, unsaponifiable matter, acid value, and peroxide value were determined according to standard IUPAC methods for the analysis of oils and fats [8]. The ester value was obtained by subtracting the acid value from the saponification value. All experiments were conducted in triplicate.

\subsection{Analysis of Fatty Acid Composition of Wheat Germ Oil}

\subsubsection{Preparation of Methyl Esters}

Methyl esters of fatty acids were prepared in accordance to the method of Morrison and Smith [9] with some modification. For sample $100 \mathrm{mg}$ adding $1 \mathrm{~mL} \mathrm{BF3/methanol} \mathrm{(14 \% )} \mathrm{and} 1 \mathrm{ml}$ hexane. The tube is vortexed and placed under nitrogen for $60 \mathrm{~min}$ at $100^{\circ} \mathrm{C}$. Esters of fatty acids were then extracted by adding $1 \mathrm{ml}$ of hexane and washing with $2 \mathrm{ml}$ of distilled water. After the centrifugation step (4500 rpm, $10 \mathrm{~min}, 20^{\circ} \mathrm{C}$ ), the supernatant is recovered in vials and then injected into the GC column.

\subsubsection{Chromatographic Analysis of the Fatty Acid Methyl Esters}

Methyl esters were analyzed by GC-type CG-2010 Plus, Shimadzu, equipped with a flame ionization detector and a capillary column of $60 \mathrm{~m}$ length, $0.25 \mathrm{~mm}$ internal diameter, the thickness of the film is 0.20 microns. The oven temperature is $200^{\circ} \mathrm{C}$. The detector and the injector are at a temperature of $250^{\circ} \mathrm{C}$. The samples were separated on the column using helium as the carrier gas with a flow rate of $0.8 \mathrm{ml} / \mathrm{min}$. The sample is injected in split mode. The temperature program used in the analysis is to keep the unit at $120^{\circ} \mathrm{C}$ for $2 \mathrm{~min}$ and then climb to $180^{\circ} \mathrm{C}$ for $2 \mathrm{~min}$ and keep the sample at $220^{\circ} \mathrm{C}$ for $25 \mathrm{~min}$. The peak integration is done on the software GC, GC solution (Shimadzu). Peak identification of fatty acids on the chromatogram is made using standard fatty acids (Restek, Food industry FAME Mix—methylene chloride $30 \mathrm{mg} / \mathrm{mL}$ ).

\subsection{Antioxidant Activity}

The antioxidant properties of defatted wheat germ extract was evaluated according to the DPPH radical scavenging activity, Rancimat method, and ABTS radical scavenging activity assays.

\subsubsection{Determination of DPPH・ Radical Scavenging Capacity}

The antioxidant activity was determined by radical scavenging ability using stable $\mathrm{DPPH}^{*}$ radical as described by Akowuah et al. [10], which measures the ability of antioxidants to quench a DPPH' stable radical. Briefly, 
$200 \mu \mathrm{L}$ of methanolic solution of tested sample at different concentration was added to $2 \mathrm{~mL}$ of methanolic solution of $\mathrm{DPPH}^{*}$ radical $(0.1 \mathrm{mM})$ and the total volume was made up to $3 \mathrm{~mL}$ with methanol. After 60 min of incubation at $30^{\circ} \mathrm{C}$ in the dark, the absorbance of the mixture was measured at $517 \mathrm{~nm}$ against methanol as blank in an UV spectrophotometer. The free radical scavenging activity of the tested samples was evaluated by comparison with a control (2 $\mathrm{mL}$ of DPPH radical solution and $1 \mathrm{~mL}$ of methanol). Each sample was measured in triplicate, and an average value was calculated. Antioxidant activity was expressed as a percentage of DPPH radical scavenging activity compared to control. Scavenging activity was calculated as follows:

$$
\text { DPPH radical-scavenging activity }(\%)=\left[\left(\mathrm{A}_{\text {Control }}-\mathrm{A}_{\text {Sample }}\right) / \mathrm{A}_{\text {Control }}\right] \times 100
$$

where A is the absorbance at $517 \mathrm{~nm}$.

\subsubsection{ABTS Radical Scavenging Assay}

The method was described by Re et al. [11]. $\mathrm{ABTS}^{+\bullet}$ was dissolved in water to a $7 \mathrm{mM}$ concentration. ABTS ${ }^{+\bullet}$ radical cation was produced by reacting ABTS stock solution with $2.45 \mathrm{mM}$ potassium per sulphate (final concentration) and allowing the mixture to stand in the dark at room temperature for $12-16 \mathrm{~h}$ before use. Because $\mathrm{ABTS}^{+\bullet}$ and potassium per sulphate react stoichiometrically at a ratio of 1:0.5, this will result in incomplete oxidation of the $\mathrm{ABTS}^{+\bullet}$. Oxidation of the $\mathrm{ABTS}^{+\bullet}$ commenced immediately, but the absorbance was not maximal and stable until more than $6 \mathrm{~h}$ had elapsed. The radical was stable in this form for more than two days when stored in the dark at room temperature. For the study of the antioxidant activity, the $\mathrm{ABTS}^{+\bullet}$ solution was diluted with ethanol to an absorbance of 0.7 at $734 \mathrm{~nm}$ and equilibrated at $30^{\circ} \mathrm{C}$. All determinations were carried out at least three times, and in triplicate, on each occasion and at each separate concentration of samples. Scavenging activity was calculated as follows:

$$
\mathrm{ABTS} \text { radical-scavenging activity }(\%)=\left[\left(\mathrm{Abs}_{\text {Control }}-\mathrm{Abs}_{\text {Sample }}\right) / \mathrm{Abs}_{\text {Control }}\right] \times 100
$$

where $\mathrm{Abs}_{\text {Control }}$ is the absorbance of ABTS radical + methanol and $\mathrm{Abs}_{\text {sample }}$ is the absorbance of ABTS radical + extract.

\subsubsection{Rancimat Method}

Measurement of the antioxidant potency in a food matrix (oil) was performed using the well-established Rancimat method [12]. The Rancimat apparatus was operated at $120^{\circ} \mathrm{C}$. A dry air flow of $20 \mathrm{l} / \mathrm{h}$ was passed through the oil sample $(5 \pm 0.001 \mathrm{~g})$ containing the antioxidant. The volatile oxidation products coming from the oxidation of the oil dissolved in cold milli-Q water $(60 \mathrm{ml})$, causing an increase in the electrical conductivity. All tests were performed in triplicate. The time (in h) taken to reach a specific conductivity value, corresponding to the flex point of the peroxidation curve, was considered as the induction time (IT). The higher the induction time the higher the antioxidant potency of the compounds.

\subsection{Microorganisms and Culture Conditions}

The following strains and incubation conditions were used to evaluate the antibacterial activity of defatted wheat germ: four food borne pathogens, Escherichia coli CIP 54.8 (E. coli) and Salmonella enterica CIP 81.32 (S. enterica) as model Gram-negative bacteria and Staphylococcus aureus CIP 76.25 (S. aureus) and Listeria monocytogenes CIP 82.110 (L. monocytogenes) as model Gram-positive bacteria, were obtained from public collection (Collection de l'Institut Pasteur (CIP), Paris, France). These strains were propagated overnight at $37^{\circ} \mathrm{C}$ in Mueller-Hinton broth (MH). The cultures obtained were diluted with Mueller-Hinton broth (MH) to obtain a final absorbance $\left(\mathrm{OD}_{630}\right)$ of 0.1 corresponding to $\sim 10^{8}$ (CFU/ml). This concentration was used for antibacterial activity experimentations.

\subsection{Evaluation of Antibacterial Activity}

\section{Bacterial Growth Inhibition}

Bacterial growth inhibition was determined using, flat-bottomed 96-well microplate. Microplate was filled with $90 \mu \mathrm{l}$ of diluted bacterial strains, with the exception of the first row of wells, which were filled with $90 \mu \mathrm{l}$ of 
broth medium, corresponding to the blank. Then, $10 \mu \mathrm{l}$ of each sample concentration (50\% initial ethanol concentration) was added in all microplate wells to have final concentration of $0.1-10 \mathrm{mg} / \mathrm{ml}$. Two controls were used in two columns of the microplate which contain $90 \mu \mathrm{l}$ of diluted bacterial strains: one with $10 \mu \mathrm{l}$ of sterile distilled water (positive control) and another with $10 \mu \mathrm{l}$ of ethanol (50\%) (negative control).

After that, the microplate was homogenized by constant shaking for 5 minutes. Bacterial growth was determined by optical density at $630 \mathrm{~nm}$ of each well on a microplate reader (multiscan GO W382TA, Thermo Scientific MIB, France). After absorbance determination at $630 \mathrm{~nm}$ for T0, the microplates were incubated, without shaking, at $37^{\circ} \mathrm{C}$ for $16-18 \mathrm{~h}$. Tests were carried out in duplicate. The antibacterial activity of compounds tested was reported as inhibition percentage (\%) by the following equation according to method [13]:

$$
\text { \% Inhibition }=1-\frac{\left(\mathrm{TF}_{\text {Sample }}-\mathrm{T}_{\text {Sample }}\right)-\left(\mathrm{TF}_{\text {Blank }}-\mathrm{T}_{\text {Blank }}\right)}{\left(\mathrm{TF}_{\text {Growth }}-\mathrm{T}_{\text {Growth }}\right)-\left(\mathrm{TF}_{\text {Blank }}-\mathrm{T}_{\text {Blank }}\right)} \times 100
$$

where $\mathrm{T}_{\text {Sample }}$ and $\mathrm{TF}_{\text {Sample }}$ corresponded to the absorbance at $630 \mathrm{~nm}$ of the strain growth in the presence of the tested compounds before (T0) and after (TF) incubation, respectively; $\mathrm{T}_{\text {Blank }}$ and $\mathrm{TF}_{\text {Blank }}$ corresponded to the Mueller-Hinton broth medium with solvent before and after incubation, respectively; and $\mathrm{T}_{\text {Growth }}$ and $\mathrm{TF}_{\text {Growth }}$ to the strain growth in the presence of the sterile distilled water (positive control) before and after incubation, respectively.

\section{Results and Discussions}

\subsection{Proximate Composition of Wheat Germ}

Wheat germ, a nutritious by-product of the flour milling industry constituting $2.5-3.0 \mathrm{~g} / 100 \mathrm{~g}$ of the grain can be separated in a fairly pure form by using a germ separator or by suitable adjustments in milling techniques. The results of the proximate chemical analysis (Table 1) indicated that raw wheat germ sample had 12.63 g/100g moisture, $27.69 \mathrm{~g} / 100 \mathrm{~g}$ crude protein, $3.08 \mathrm{~g} / 100 \mathrm{~g}$ ash, and $1.54 \mathrm{~g} / 100 \mathrm{~g}$ crude fiber. The total carbohydrate by difference was found to be $46.07 \mathrm{~g} / 100 \mathrm{~g}$, whereas the total lipids content of wheat germ was $9 \mathrm{~g} / 100 \mathrm{~g}$. Previous studies reported higher values of ash content for wheat germ (18.01 g/100g FW) [2].

The crude fat content of wheat germ used in this study was $8.99 \mathrm{~g} / 100 \mathrm{~g}$, and this agrees with the $7 \%-10 \%$ results reported by some researchers [2] [14]. The oil yield from wheat germ obtained in this study was lower than that of safflower oil (32\%), rapeseed (39\%), soybean oil (20\%) and linseed oil (34\%), both produced on commercial scale [15]. The defatted residues consequently became more replete with carbohydrates which could be processed further into livestock feeds, syrups, and other forms for diverse purposes, thus suggesting solvent extraction as the most acceptable and economical method of oil extraction relative to those enumerated.

The crude protein content of wheat germ is comparable to those reported for some conventional oilseeds like safflower seed (29.3\%), sunflower (19.5\%), and peanut (30.3\%). The protein compares favourably with the value of 9.8\% reported for wheat flour [16], 6.34\% reported for jackfruit seed flour [17]. Wheat germ could therefore serve as alternative source of protein and oil for man.

Wheat germ was also found to be a rich source of carbohydrates (46.07 g/100g). Thus being an excellent source of energy (375 kcal/100g). The low moisture content 12.63 of wheat germ remains an asset in storage and preservation of the nutrients. The germ could therefore serve as a cheap source of raw material for the food and oleochemical industries, and would also yield stable oil for diverse purposes and applications including shampoos, soaps, and by-products, margarine and salad and cooking oils. Therefore, wheat germ, with its inherent nutritional, could serve as good alternative to imported vegetable oils in food products.

Table 1. Chemical composition of wheat germ.
\begin{tabular}{|ccccccccc}
\hline Parameter (\%) & Moisture & Ash & Crude fat & Crude protein & Crude fiber & $\begin{array}{c}\text { Carbohydrate* } \\
\text { * Food energy value } \\
\text { (kcal/100g) }\end{array}$ \\
\hline Wet weight & $12.63 \pm 0.19$ & $3.08 \pm 0.18$ & $8.99 \pm 0.32$ & $27.69 \pm 0.44$ & $1.54 \pm 0.18$ & 46.07 & 375.95 \\
Dry weight & 0.0 & 3.53 & 10.29 & 31.69 & 1.76 & 52.73 & 430.30 \\
\hline
\end{tabular}

Data are mean \pm SD of three replicates. *By difference. 


\subsection{Physicochemical Properties of Wheat Germ Oil}

Preliminary characterization of wheat germ oil was carried out by collecting data (Table 2) on some bulk physicochemical properties of the oil. Refractive index is the degree of the deflection of a beam light that occurs when it passes from one medium to the other. Refractive index generally shed light on structural properties such as average molecular mass and degree of unsaturation of the fatty acids in oils and fats. Refractive index of wheat germ oil was found to be 1.4728 . This value indicates the presence of long chain unsaturated fatty acids in germ oil.

The saponification value (SV) of 191.22, $\mathrm{mg} \mathrm{KOH/g}$ for wheat germ oil also pointed in the direction of presence of long chain unsaturated fatty acids in germ oil. The high saponification value of this oil suggested its potential use in liquid soap and shampoo production [18]. Unsaponifiable matter (USM) consists of minor components accompanying triacylglycerols (sterols, tocopherols, lipopigments and hydrocarbons) and makes up $0.5 \%$ $2.5 \%$, exceptionally $5 \%-6 \%$ of vegetable oils. The oil showed a high content of the unsaponifiable matter (4.69\%) i.e., the phytosterols, tocopherols and tocotrienols. Therefore, the addition of USM isolated from wheat germ oil can be proved to retard oxidation in vegetable oils and model lipids subjected to heating. The antioxidant activity of tocopherols is well documented. Other unsaponifiable components including sterols, carotenoids and squalene may protect the unsaturated fatty acids from being rancid as well [19].

Iodine value measures the unsaturation content in the oil sample. A higher iodine value indicates a higher degree of unsaturation and consequently higher refractive indices. For this study, the oil showed a high iodine value 115.47 ( $\mathrm{g} \mathrm{I}_{2} \cdot 100 \mathrm{~g}^{-1}$ oil) due to its high unsaturated fatty acid content such as oleic and linoleic acid (Table 3). Its iodine value places it in the semi-drying oil group. This iodine value suggests its use in production of alkyd resin, shoe polish, and varnishes.

Formerly it was believed that wheat germ oil had poor keeping qualities. Jamieson and Baughman [20] reported that a sample of the oil which at first contained 5.65\% of free fatty acids after a year's storage had $43.8 \%$. Later investigators have found that, contrary to former reports, the oil has excellent keeping qualities as shown by the slight increase in the quantity of free fatty acids, even when the oil is held from one to three years after its extraction. These differences in free fatty acids can be related with the wild origin, maturation stage of germ and different storage condition. The wheat germ used in this investigation was several weeks old before the extraction of the oils. Both acid value and peroxide value were high in wheat germ oil (Table 2). Acid value is a measure of the degree of lipid hydrolysis and separation of fatty acids from glycerol while peroxide value is a measure of lipid oxidation. Wheat germ, from which the oil was extracted, had been on the shelf for a long time according to the production date and oil deterioration is quite possible. In addition, wheat germ oil is generally characterized by higher free fatty acids [21].

Table 2. Physico-chemical characteristics of wheat germ oil ${ }^{\mathrm{a}}$.

\begin{tabular}{cc}
\hline Parameter & Value \\
Refractive index & $1.4728 \pm 0.17$ \\
Color (as absorbance at $420 \mathrm{~nm}$ ) & $1.35 \pm 0.22$ \\
Specific gravity & $0.9257 \pm 0.44$ \\
Acid value (mg/g oil) & $13.88 \pm 0.33$ \\
Acidity (as \% oleic acid) & $8.33 \pm 0.19$ \\
Saponification value (mg/g oil) & $191.22 \pm 0.15$ \\
Ester value (mg/g oil) & $177.34 \pm 0.18$ \\
Iodine value (g $\mathrm{I}_{2} / 100 \mathrm{~g}$ of oil) & $115.47 \pm 0.22$ \\
Peroxide value (meq $\mathrm{O}_{2} / \mathrm{kg}$ oil) & $16.35 \pm 0.13$ \\
Unsaponifable matter (\%) & $4.69 \pm 0.33$
\end{tabular}

${ }^{\mathrm{a}}$ Data are mean $\pm \mathrm{SD}$ of three replicates. 
Table 3. Fatty acid composition of wheat germ oil ${ }^{\mathrm{a}}$.

\begin{tabular}{|c|c|}
\hline Fatty acid & Concentration (\%) \\
\hline C14 myristic & $0.13 \pm 0.23$ \\
\hline C15 pentadecanoic & $0.16 \pm 0.45$ \\
\hline C16 palmitic & $17.42 \pm 0.18$ \\
\hline C16:1 palmitoleic & $0.23 \pm 0.22$ \\
\hline C18:1n-9t eliadic & $0.85 \pm 0.11$ \\
\hline C18:1n-9c cis oleic & $16.14 \pm 0.16$ \\
\hline C18:2n-6t trans linoleic & $0.71 \pm 0.10$ \\
\hline C18:2n-6c cis linoleic & $55.05 \pm 0.15$ \\
\hline C18:3n-3 linolenic & $7.95 \pm 0.44$ \\
\hline C21 heneicosylic & $1.36 \pm 0.25$ \\
\hline Total saturated & 19.07 \\
\hline Total unsaturated & 80.93 \\
\hline$\sum$ MUFA & 17.22 \\
\hline$\sum$ PUFA & 63.71 \\
\hline n6/n3 & 6.92 \\
\hline pufa/sfa & 3.34 \\
\hline sfa/pufa & 0.30 \\
\hline oleic/linoleic & 0.29 \\
\hline $\mathrm{S} / \mathrm{U}$ & 0.24 \\
\hline
\end{tabular}

${ }^{\mathrm{a}}$ Mean values \pm standard deviation of triplicate determinations are reported. Results are expressed as percentage of the total fatty acids.

\subsection{Fatty Acid Composition of Wheat Germ Oil}

Physiological and biological characteristics of oils are influenced by the kinds and proportions of the fatty acid components and their position on the glycerol radical, thus the stereospecific analysis of fatty acids in the triacylglycerol was considered important for use of the lipid for both dietary and industrial purposes [22]. In profiling the principal components carried out the determination of the FA compositions of the test seed oil by GC.

A striking feature of wheat germ lipids was the relatively high level of polyunsaturated fatty acids (PUFA), especially linoleic fatty acid which was estimated at higher levels (55\%) (Table 3).

Linoleic acid, the essential fatty acid, is one of the most important polyunsaturated fatty acids in human food because of its prevention of cardiovascular heart disease (CHD). With regard to the issue of fatty acids, our data are in accord with those of Ramadan et al. [14] which show that the proportion of linoleic followed by oleic and palmitic as the major fatty acids, which together comprise more than $92 \mathrm{~g} / 100 \mathrm{~g}$ of the total identified.

The fatty acid compositions of wheat germ oil, compare favourably with those reported for some conventional oilseeds like soybean (C18:1, 25\%, C18:2, 51\%, C18:3, 9\%), and sunflower (C18:1, 17\%, C18:2, 72\%) [23]. The oleic acid content of wheat germ oil is close to that of most other vegetable oils, such as sunflower oil (23.6\%), soybean oil (24.9\%), or corn oil (23.8\%), and can thus serve as a substitute for these oils especially in times of scarcity.

From the analysis of the summation of FAs, it can be seen that the MUFAs (16:1, 18:1n-9t, and 18:1n-9c) totaled $17.22 \%$ of the total fatty acids present in the sample, 18:1n-9c being responsible for almost all of this total. These results are considered very advantageous for health as this class of fatty acids is responsible for reducing LDL and total cholesterol, thereby preventing heart attacks, thrombosis and activates blood content of soluble 
glucose; thus its digestion is recommended.

The linoleic fatty acids (belonging to the omega-6) and $\alpha$-linolenic fatty acids (belonging to the omega-3) are considered essential, as they cannot be synthesized by mammals and must be obtained from food. $\omega-6$ and $\omega-3$ fatty acids are required for the normal growth, health and development of body [24]. According to Ribarova et al. [25], polyunsaturated fatty acids must make up $10 \%$ of the total energy ingested for an adequate diet as far the correct ingestion of lipids is concerned. Furthermore, omega-3 family of fatty acids may have a positive effect in the treatment of depression and schizophrenia [26]. The consumption of 18:2n-6 (linoleic acid) is commonly thought to be capable of reducing LDL and total cholesterol. The presence of this polyunsaturated fatty acid in the germ oil is expected to impart semi-drying property and can be used in surface coating industries.

Several scientific studies have shown that $\mathrm{n} 3$ fatty acids have benefits for lowering CHD risk. It has been also suggested that $\mathrm{n} 3 / \mathrm{n} 6$ ratio of 10 or less results in a reduction in fatal CHD risk [27]. Wheat germ oil also has very high unsaturated and polyunsaturated fatty acid content and an excellent $n 3 / n 6$ fatty acid ratio (1/7). The SFAs found in the sample were 14:0, 15:0, 16:0, and 21:0, and their summation was 19.07\%. The ratio of saturated fatty acids to unsaturated fatty acids (S:U), a commonly used criteria to describe the nutritional value of fat, was low for wheat germ oil (0.24), indicating its potential as an alternative edible oil feed source.

Since oils rich in PUFA and minor components are required for the normal physiological activities, blending germ oil with other edible oils of the diet in wheat growing countries may be useful to provide health benefits.

\subsection{Antioxidant Activity}

Autoxidation is a complex process, but model studies have revealed that the rate of autoxidation is affected by fatty acid composition, degree of unsaturation, the presence and activity of pro- and antioxidants, partial pressure of oxygen, the surface exposed to oxygen (dispersed systems) and storage conditions. Antioxidants inactivate reactive radicals at the initial steps of autoxidation, thus avoiding the propagation of the radical chain reaction. Radical scavengers have attracted special interest in nutrition and medicine, because they may protect human cells from free radicals, thereby preventing diseases, including cancer [14]. Natural antioxidant activity depends on various parameters, such as the reaction mechanism, the isolation procedures, purity of active compounds, as well as the test system and substrate to be protected by the antioxidant. The antioxidant properties of DWG extract cannot be evaluated by just one method due to the chemical nature of the extract's constituents. The use of several methods is recommended to assess and compare the antioxidant capacity of a sample. Here we applied assays of DPPH radical scavenging activity, ABTS radical scavenging activity and Rancimat method.

\subsubsection{Scavenging of DPPH Radicals}

DPPH is a stable organic free radical that is dissolved in methanol and its purple colour shows maximum absorbance at $517 \mathrm{~nm}$. When DPPH radicals encounter a proton-donating substance such as an antioxidant, the radicals would be scavenged and the colour from the DPPH assay solution becomes light yellow resulting in a decrease in absorbance. It can accommodate many samples in a short period and is sensitive enough to detect active ingredients at low concentrations [28]. Thus, the DPPH radicals have been widely used to determine the free radical scavenging ability of various samples. In this assay, results are expressed as the ratio percentage of the absorbance decrease of DPPH radical solution in the presence of extract at $517 \mathrm{~nm}$ to the absorbance of DPPH radical solution at the same wavelength. Figure 1 shows the results of scavenging DPPH radical ability of DWG at various concentrations and compared with those of BHA and BHT. DWG showed DPPH scavenging activities in a concentration dependent manner. The antioxidative activity of DWG was close to that of synthetic antioxidants BHA and BHT. A similar trend was observed in a study of the antioxidant activity of the field horsetail (tsukushi) Equisetum arvense L. extracts [19]. The $\mathrm{EC}_{50}$ (meaning the concentration that causes a decrease in the initial DPPH concentration by 50\%) is a parameter widely used to measure the antiradical efficiency, which was obtained by interpolation from linear regression analysis. A lower $\mathrm{EC}_{50}$ value is associated with a higher radical scavenging activity. The result showed that DWG is a free radical inhibitor, as well as a primary antioxidant that reacts with free radicals, which may limit the occurrence of free radical damage in human body.

\subsubsection{ABTS Radical Scavenging Activity}

The antioxidant potential of a compound is different according to different antioxidant assays since the interac- 


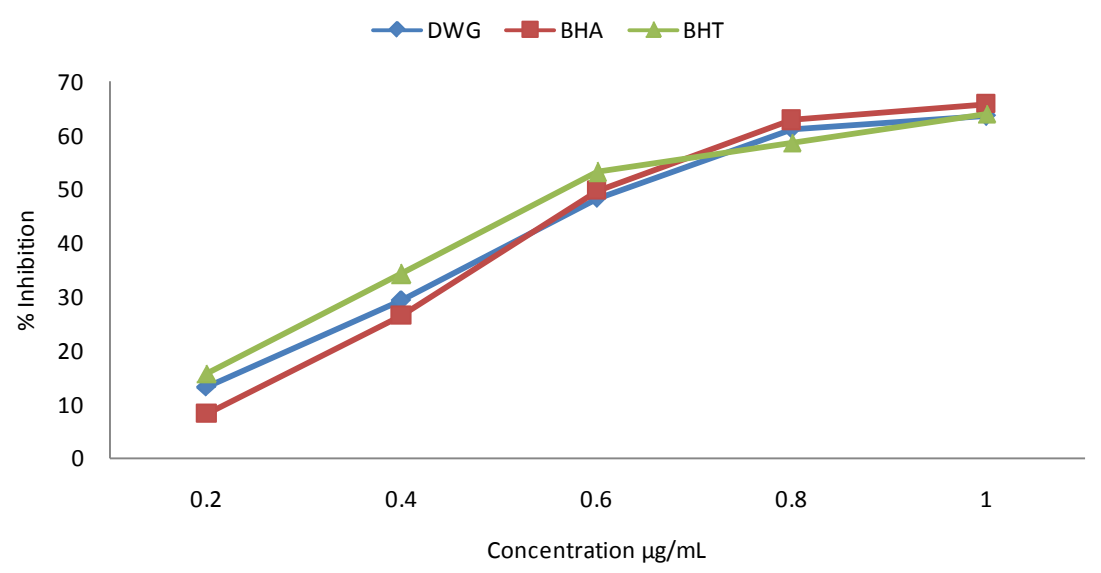

Figure 1. Scavenging activity of defatted wheat germ extract against DPPH radical at different concentrations. Data are mean \pm SD of three determinations.

tion of the antioxidant with other compounds plays an important role in the activity. Dramatic differences in the relative antioxidant potential of model compounds were observed when one model compound is strongly antioxidant with one method and prooxidant with another [28]. The ABTS radical cation decolourisation test is another method widely used to assess antioxidant activity. The original ABTS assay was based on the activation of metmyoglobin by hydrogen peroxide in the presence of ABTS. Reduction in colour indicates reduction of ABTS radical. The ABTS radical cation is more reactive than the DPPH radical, and reaction of the ABTS radical cation with an antioxidant is taken as complete within $1 \mathrm{~min}$. As shown in Figure 2, DWG extract reduced the absorbance at $734 \mathrm{~nm}$, and the concentration of the extract was directly proportional to the reduction. DWG extract had comparable scavenging ability to the synthetic antioxidants BHA and BHT. Scavenging of the ABTS ${ }^{+}$ radical by the extract was found to be higher than that of DPPH radical.

Factors such as stereoselectivity of the radicals and the solubility of extracts in different test systems have been reported to affect the capacity of extracts to react with and quench different radicals [29]. Wang et al. [30] found that some compounds possessing $\mathrm{ABTS}^{+}$-scavenging activity did not show DPPH-scavenging activity. This was not the case in the present study. From a mechanistic standpoint, the DPPH radical scavenging assay could reflect the capacity of the extract transferring electrons or hydrogen atoms, while the ABTS radical scavenging activity could reflect the hydrogen donating and the chain-breaking capacity of the extract [19].

\subsubsection{Rancimat Method}

The oxidative stability of oils are affected by many factors, including fatty acid composition, concentration and stability of antioxidants in the oil, and the presence of prooxidant compounds, such as free fatty acids, lipid peroxides, or prooxidant metals. The Rancimat method is an accelerated aging test (taking several hours to a day, depending on the oil and test temperature) used to establish the relative oxidative stability of oils, as measured by the induction time (called the oxidative stability index, OSI) for an oil to begin oxidizing under controlled temperature and air flow conditions. Rancimat results, due to the formation of secondary reaction products, showed a pattern in good agreement with that of ABTS and DPPH methods. As can be seen in Figure 3, stabilization factor of DWG extract was (2.1). Considering the results of all three assays, it may be anticipated that the extract of defatted wheat germ has antioxidant activity.

\subsection{Antibacterial Activity}

The antibacterial ability of defatted wheat germ was evaluated as natural antibacterial agents against certain bacteria known to cause infection in humans. Staphylococcus aureus and Escherichia coli are of the major causes of hospital-acquired infections [31]. These organisms occur naturally in and on human body. The antibacterial activity of DWG extract at different concentrations in vitro test against Listeria monocytogenes, Staphylococcus aureus, Salmonella enterica and Escherichia coli bacteria were showed in Figure 4. The extract evidenced antibacterial activity, and showed different bacterial growth inhibition for each microorganism. According to the 


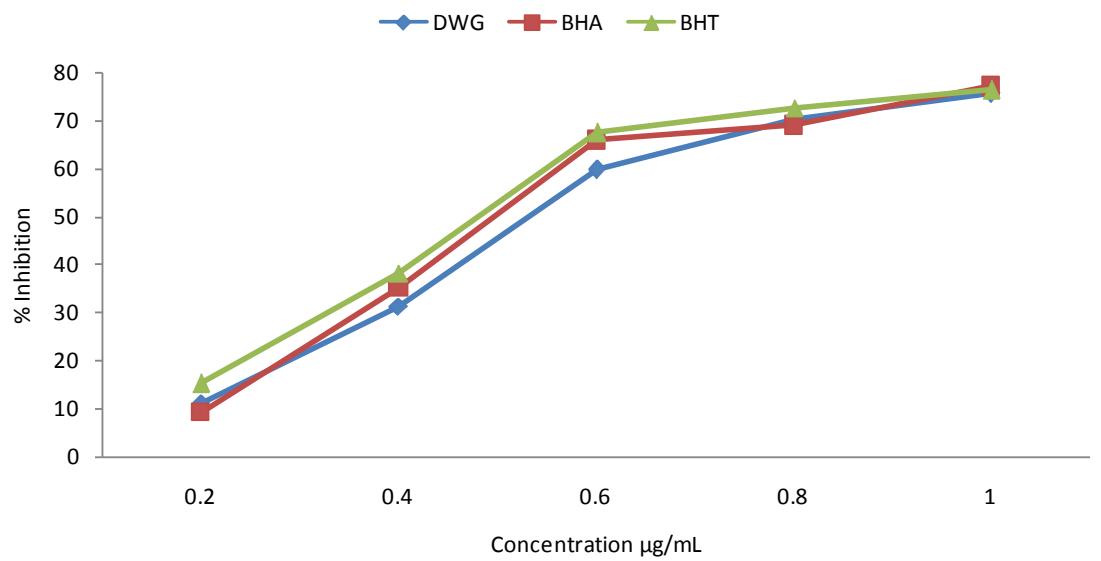

Figure 2. Scavenging activity of defatted wheat germ extract against ABTS radical at different concentrations. Data are mean \pm SD of three determinations.

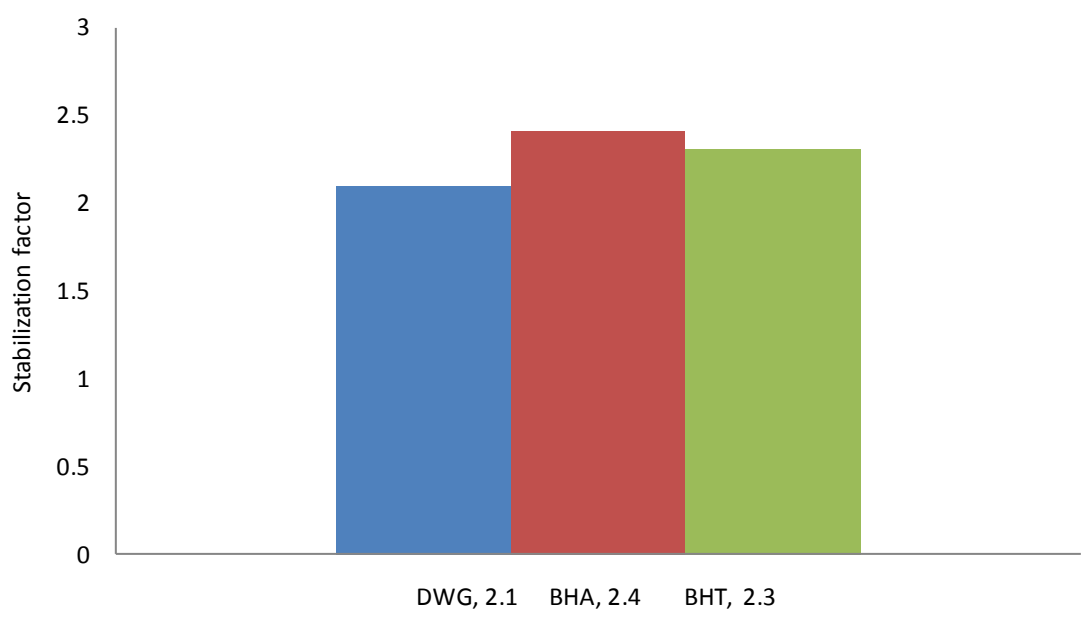

Figure 3. Oxidative stability of defatted wheat germ extract by Rancimat method. Data are mean \pm SD of three determinations.

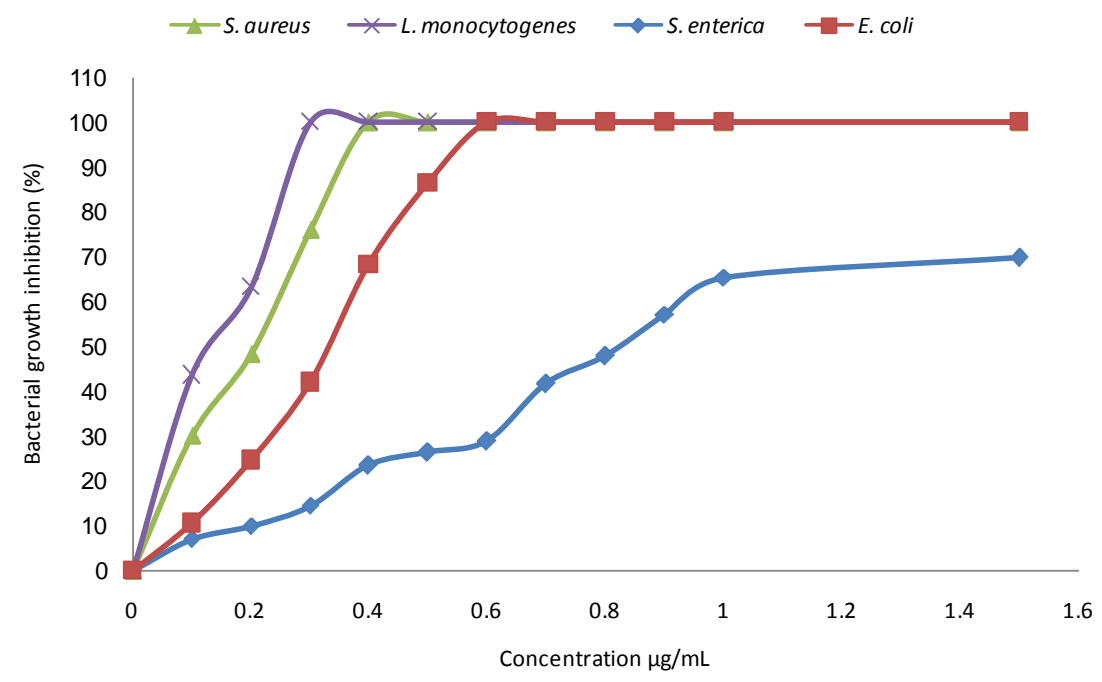

Figure 4. Antibacterial activity of defatted wheat germ extract against the bacterial strains pathogens tested. Values are mean \pm standard deviation $(n=3)$. 
results obtained, all the Gram-positive bacteria tested were highly sensitive to a lower concentration of DWG especially against $L$. monocytogenes. Gram-negative bacteria (E. coli, S. enterica) were also sensitive for DWG extract. However, it was found that the highest dose $(1.5 \mathrm{mg} / \mathrm{mL})$ of DWG was needed to inhibit the growth of S. enteric only about $70 \%$. In addition, $L$. monocytogenes and S. aureus were the most sensitive strains, followed by E. coli, and S. enterica.

In the present work, we could verify that the Gram-positive bacteria were more sensitive to DWG than the Gram-negative bacteria. The most plausible explanation for the lack of sensitivity shown by Gram-negative bacteria could be attributed to their outer membrane that inhibits and/or retards the penetration of DWG at lower concentrations, but this effect is as yet not fully explained. Another possible reason might be the presence of multidrug resistance pumps (MDRs), which extrude amphipathic toxins across the outer membrane. In addition, this bacterial group has a higher lipid amount than that observed in Gram-positive.

On the basis of the results it is possible that defatted wheat germ extract could be of value as easily accessible source of natural antioxidant and antibacterial as a food supplement or in the pharmaceutical industry.

\section{Conclusions}

The basic chemical composition analyses of wheat germ sample put in evidence the high values of dry matter, considerable amounts of total protein and fat contents and low ash content. In addition, ten different individual fatty acids were identified, with 18:2n-6 linoleic predominating in the studied sample by GC. The oil showed a high content of the essential fatty acid linoleic acid, saponification and unsaponifiable matter, suggesting that this oil might be used as cosmeceutical agent, and for making skin creams and lotions, soap, hair shampoo and a source of minor components in our daily food menu to promote good health. Soybean oil is the most common feedstock for biodiesel, but this study indicates that from the standpoint of fatty acid composition and oxidative stability, oil extracted from wheat germ will be an economical alternative. Considering that over 120,000 tons WG with roughly $10 \%$ oil are produced from wheat milling each year, enough oil can be recovered to decrease the high demand for conventional vegetable oils and therefore decrease their prices. In this study, DWGE exhibits antioxidant activity in DPPH radical scavenging assay, ABTS radical scavenging assay, and oxidative stability in Rancimat method. It is also notable that this product is a potential source of antibacterial agents that act mainly on Gram-positive and Gram-negative bacteria. Thus, it can be an efficient protective agent for use as antioxidant and antibacterial additives in food systems.

Overall, these results show that these by-products can be used as a rich source of bioactive compounds of beneficial effects on health as well as increasing the competitiveness of the company that generates theses residues economically profitable.

\section{Acknowledgements}

Our gratitude is extended to Dr. Mohamed H. Roby from Fayoum University, Faculty of Agriculture, Food Science and Technology, Egypt, for helpful revision.

\section{References}

[1] Mielke, T. (2011) Oil Word Annual 2011. ISTA Mielke Gmbh, Hamburg.

[2] de Vasconcelos, M.C., Bennett, R., Castro, C., Cardoso, P., Saavedra, M.J. and Rosa, E.A. (2013) Study of Composition, Stabilization and Processing of Wheat Germ and Maize Industrial By-Products. Industrial Crops and Products, 42, 292-298. http://dx.doi.org/10.1016/j.indcrop.2012.06.007

[3] Elliott, D.C., Orth, R.J., Gao, J., Werpy, T.A., Eakin, D.E., Schmidt, A.J., et al. (2002) Biorefinery Concept Development Based on Wheat Flour Milling. Fuel Chemistry Division Preprints, 47, 361-362.

[4] Zhu, K.X., Zhou, H.M. and Qian, H.F. (2006) Proteins Extracted from Defatted Wheat Germ: Nutritional and Structural Properties. Cereal Chemistry, 83, 69-75. http://dx.doi.org/10.1094/CC-83-0069

[5] Megahad, O.A. and El Kinawy, O.S. (2002) Studies on the Extraction of Wheat Germ Oil by Commercial Hexane. Grasas y Aceites, 53, 414-418. http://dx.doi.org/10.3989/gya.2002.v53.i4.339

[6] AOAC (1990) Official Methods of Analysis. 15th Edition, Association of Official Analytical Chemists, Washington DC.

[7] Lee, Y.C., Oh, S.W., Chang, J. and Kim, I.H. (2004) Chemical Composition and Oxidative Stability of Safflower Oil 
Prepared from Safflower Seed Roasted with Different Temperatures. Food Chemistry, 84, 1-6. http://dx.doi.org/10.1016/S0308-8146(03)00158-4

[8] Dieffenbacher, A. and Pocklington, W.D. (1987) Standard Methods for the Analysis of Oils, Fats and Derivatives. In: International Union of Pure and Applied Chemistry, 7th Edition, Blackwell Scientific, Oxford.

[9] Morrison, W.R. and Smith, L.M. (1964) Preparation of Fatty Acid Methyl Esters and Dimethylacetals from Lipids with Boron Fluoride-Methanol. Journal of Lipid Research, 5, 600-608.

[10] Akowuah, G.A., Ismail, Z., Norhayati, I. and Sadikun, A. (2005) The Effects of Different Extraction Solvents of Varying Polarities of Polyphenols of Orthosiphon stamineus and Evaluation of the Free Radical-Scavenging Activity. Food Chemistry, 93, 311-317. http://dx.doi.org/10.1016/j.foodchem.2004.09.028

[11] Re, R., Pellegrini, N., Proteggente, A., Pannala, A., Yang, M. and Rice-Evans, C.A. (1999) Antioxidant Activity Applying an Improved ABTS Radical Cation Decolorization Assay. Free Radical Biology Medicine, 26, 1231-1237. http://dx.doi.org/10.1016/S0891-5849(98)00315-3

[12] Ranalli, L., Pollastri, S., Contento, E. and Iannucci, L. (2003) Effect of Olive Paste Kneading Process Time on the Overall Quality of Virgin Olive Oil. European Journal of Lipid Science and Technology, 105, 57-67. http://dx.doi.org/10.1002/ejlt.200390018

[13] Cueva, C., Moreno-Arribas, M.V., Requena, T., Rodriguez, J.M., Vicente, F. and Basilio, A. (2010) Antimicrobial Activity of Phenolic Acids against Commensal, Probiotic and Pathogenic Bacteria. Research in Microbiology, 161, 372382. http://dx.doi.org/10.1016/j.resmic.2010.04.006

[14] Ramadan, M.F., Showky, H.S. and Sulieman, A.M. (2008) Comparison between the Effect of $\gamma$-Irradiation and Roasting on the Profile and Antioxidant Activity of Wheat Germ Lipids. Grasas y Aceites, 59, 166-173. http://dx.doi.org/10.3989/gya.2008.v59.i2.506

[15] Bockisch, M. (1998) Fats and Oils Handbook. American Oil Chemists Society, Champaign, 175-344.

[16] Akubor, P.I. and Badifu, G.I.O. (2004) Chemical Composition, Functional Properties and Baking Potential of African Breadfruit Kernel and Wheat Flour Blends. International Journal of Food Science and Technology, 39, 223-229. http://dx.doi.org/10.1046/j.0950-5423.2003.00768.x

[17] Mukprasirt, A. and Sajjaanantakul, K. (2004) Physico-Chemical Properties of Flour and Starch from Jackfruit Seeds (Artocarpus heterophyllus Lam.) Compared with Modified Starches. International Journal of Food Science and Technology, 39, 271-276. http://dx.doi.org/10.1111/j.1365-2621.2004.00781.x

[18] Akbar, E., Yakoob, Z., Kamarudin, S.K., Ismail, M. and Salimon, J. (2009) Characteristic and Composition of Jatropha curcas Oil Seed from Malaysia and Its Potential as Biodiesel Feedstock. European Journal of Scientific Research, 29, 396-403.

[19] Zhu, K.X., Lian, C.X., Guo, X.N., Peng, W. and Zhou, H.M. (2011) Antioxidant Activities and Total Phenolic Contents of Various Extracts from Defatted Wheat Germ. Food Chemistry, 126, 1122-1126. http://dx.doi.org/10.1016/j.foodchem.2010.11.144

[20] Jamieson, S.G. and Baughman, F.W. (1992) Wheat Germ Oil. Oil and Soap.

[21] Kahtani, H.A. (1989) Studies of Saudi Arabian Locally Produced Wheat Germ. Food Chemistry, 34, 121-130. http://dx.doi.org/10.1016/0308-8146(89)90080-0

[22] Yoon, S.H. and Kim, E. (2003) Recent Progress in Enzymatic Production of Structured Lipids. Food Science and Biotechnology, 12, 721-726.

[23] Canvin, D.T. (1965) The Effect of Temperature on the Oil Content and Fatty Acid Composition of the Oils from Several Oil-Seed Crops. Canadian Journal of Botany, 43, 63-65. http://dx.doi.org/10.1139/b65-008

[24] Moreira, A.V.B. and Mancini-Filho, J. (2004) Influência dos compostos fenólicos de especiarias sobre a lipoperoxidação e o perfil lipídico de tecidos de ratos. Revista de Nutrição, 17, 411-424.

http://dx.doi.org/10.1590/S1415-52732004000400002

[25] Ribarova, F., Zanev, R., Shishkov, S. and Rizov, N. (2003) $\alpha$-Tocopherol, Fatty Acids and Their Correlations in Bulgarian Foodstuffs. Journal of Food Composition and Analysis, 16, 659-667. http://dx.doi.org/10.1016/S0889-1575(03)00079-6

[26] Schram, L.B., Nielsen, C.J., Porsgaard, T., Nielsen, N.S., Holm, R. and Mu, H. (2007) Food Matrices Affect the Bioavailability of $(n-3)$ Polyunsaturated Fatty Acids in a Single Meal Study in Humans. Food Research International, 40, 1062-1068. http://dx.doi.org/10.1016/j.foodres.2007.06.005

[27] Dunford, N.T. and Zhang, M. (2003) Pressurized Solvent Extraction of Wheat Germ Oil. Food Research International, 36, 905-909. http://dx.doi.org/10.1016/S0963-9969(03)00099-1

[28] Mohdaly, A.A., Sarhan, M.A., Smetanska, I. and Mahmoud, A. (2010) Antioxidant Properties of Various Solvent Extracts of Potato Peel, Sugar Beet Pulp and Sesame Cake. Journal of the Science of Food and Agriculture, 90, 218-226. 
$\underline{\text { http://dx.doi.org/10.1002/jsfa.3796 }}$

[29] Yu, L., Haley, S., Perret, J., Harris, M., Wilson, J. and Qian, M. (2002) Free Radical Scavenging Properties of Wheat Extracts. Journal of Agriculture and Food Chemistry, 50, 1619-1624. http://dx.doi.org/10.1021/jf010964p

[30] Wang, M., Li, J., Rangarajan, M., Shao, Y., La-Voie, E.J., Huang, T. and Ho, C. (1998) Antioxidative Phenolic Compounds from Sage (Salvia officinalis). Journal of Agriculture and Food Chemistry, 46, 4869-4873. http://dx.doi.org/10.1021/jf980614b

[31] Huang, Y.C., Chou, Y.H., Su, L.H., Lien, R.I. and Lin, T.Y. (2006) Methicillin-Resistant Staphylococcus aureus Colonization and Its Association with Infection among Infants Hospitalized in Neonatal Intensive Care Units. Pediatrics, 118, 469-474. http://dx.doi.org/10.1542/peds.2006-0254 
Scientific Research Publishing (SCIRP) is one of the largest Open Access journal publishers. It is currently publishing more than 200 open access, online, peer-reviewed journals covering a wide range of academic disciplines. SCIRP serves the worldwide academic communities and contributes to the progress and application of science with its publication.

Other selected journals from SCIRP are listed as below. Submit your manuscript to us via either submit@scirp.org or Online Submission Portal.
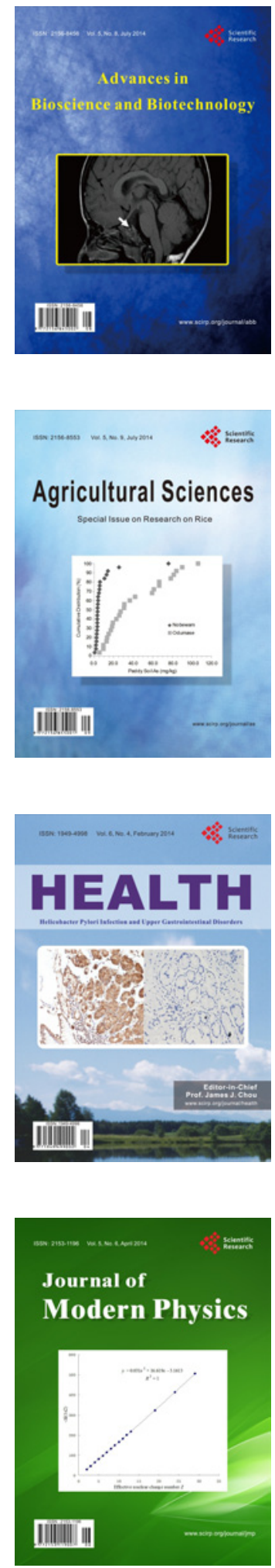
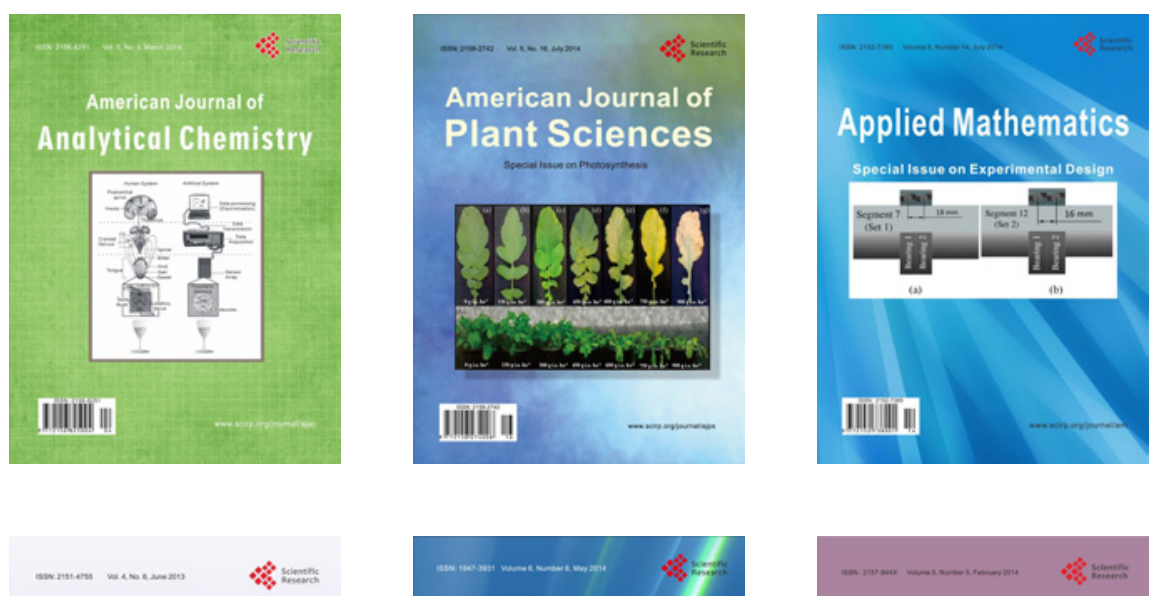

Creative Education
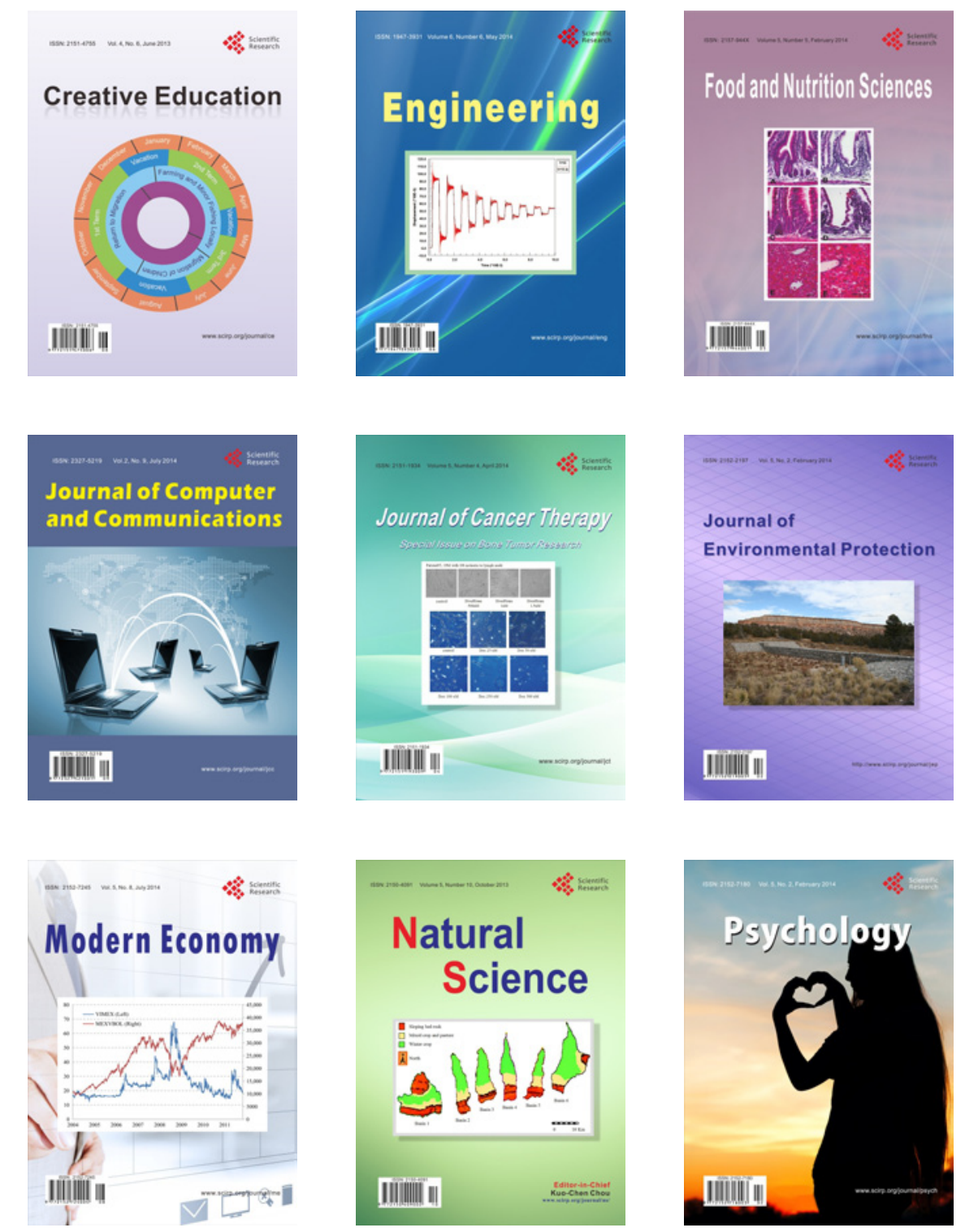